\title{
DEAD KINGS AND NATIONAL MYTHS: WHY MYTHS OF FOUNDING AND MARTYRDOM ARE IMPORTANT ${ }^{23}$
}

\author{
Sabrina P. RAMET, ${ }^{24}$ \\ The Norwegian University of Science \& Technology
}

\begin{abstract}
National myths are useful, even fundamental, in establishing the legitimacy of a given regime. In the European context, states have sometimes had recourse to myths around medieval kings. King Arthur in England, King Olav in Norway, King István (Stephen) in Hungary, and Prince Lazar in Serbia,- all canonized except for the Celtic King, Arthur - have figured in the national myths of their respective countries. Both Olav and Lazar are said to have had visions of heaven the evening before taking their troops into battle, both died resisting Ottoman forces, both are said to have welcome martyrdom, and both, as well as István, have been credited with performing miraculous cures for pilgrims visiting their graves. All four myths were put to political use: The cult of King Arthur, who led the Celts in an effort to stave off invading Angles and Saxons in the late fifth and early sixth centuries, was used to legitimate the rule of the House of Normandy, which came to power by defeating the army of the Saxon king in 1066. The cult of King-Saint Olav (1030) contributed to the strengthening of Christianity and a sense of national consciousness among Norwegians, while the canonization of King István in 1083 play the same dual role among Hungarians. Finally, in Serbia, the promotion of the cult of Prince Lazar (1389), said to have been canonized, was actively promoted during World War Two and subsequently put to use in the late 1980s and early 1990s to inspire Serbia's expansionist program.
\end{abstract}

Keywords: national myths, medieval kings, martyrdom, battle, sainthood

\section{Introduction}

The use of myths and religion in politics has a long history. Myths can establish a claim to dynastic legitimacy, to coveted territory, to glory, even to sainthood on the part of the central figure in a myth. Canonization is, in its own right, an especially powerful tool. There are, of course, diverse reasons for elevating someone to sainthood - among them, the desire to hold up for emulation a particularly pious and kind person, the wish to gratify the inhabitants of a certain country or region by honoring one of their own, the calculation that the creation of a national saint will help to promote the Christianization of a land in which pre-Christian beliefs still hold some

23 This is an abridged version of a chapter originally published in Sabrina P. Ramet, Ola Listhaug, and Dragana Dulić (eds.), Civic and Uncivic Values: Serbia in the post-Milošević era (Budapest \& New York: Central European University Press, 2011).

24 Contact address: sabrina.ramet@ntnu.no. 
sway, and even the endeavor to delegitimate a regime, as per the canonization of Tsar Nicholas II by the Russian Orthodox Church in 2000, which served to complete the delegitimation of the Bolsheviks, now cast as slayers of a saint. Of particular interest to us here, however, is the conferral of sainthood upon a king, as a device to confer legitimacy upon that king's line or to sacralize the cause allegedly championed by that king (Goodich 1979, p. 295; McKenna 1970, p. 609).

Myths may evolve and the representation of a king may change over time; in this regard, Serbia is no exception. In fact, where Serbia is concerned, one can speak of a choice among a number of possible candidates for the role of central mythical hero: To begin with, one might think of Saint Sava (1175-1235), one of the sons of Stefan Nemanja and Serbia's first archbishop. Recognized as Serbia's most important saint, Sava established the Serbian Orthodox Church. His importance is emphasized by the dedication of Serbia's largest cathedral to his memory. But Saint Sava is ill equipped to serve as the central figure in the national myth, since he was not a political figure. A second candidate might be Tsar Dušan the Mighty (Stefan Uroš IV Dušan, 1308-1355). Dušan, who reigned as King of Serbia from 1331 to 1346 and thenceforth as emperor (tsar), extended the borders of the state until it became one of Europe's larger states and promulgated a legal code; he defeated Hungary on two separate occasions and annexed a large portion of Byzantine territory in southeastern Europe. He has often been described as the greatest Serbian ruler of all time. However, in 1354, hoping that Pope Innocent IV would appoint him to command the latest crusade against the Turks, Tsar Dušan sent a legation to Rome to offer, in exchange for the pope's endorsement, to recognize the pope as the successor of St. Peter and Vicar of Christ (Emmert 1993, p. 3). Insofar as this would have meant abandoning the Orthodox faith for the Catholic faith, Dušan was not the ideal choice to play the role of central figure in the national myth.

A third possibility was Stefan Nemanja (1109-1199), who reigned as Grand Prince from 1166 until his abdication in 1196. He might seem to have been an ideal choice insofar as he both unified various small Serb states into a single state, thus ranking as a state-builder, and achieved sainthood when, after his death, several miracles were attributed to his intercession. He also had good claims to be viewed as a defender of the Christian faith, insofar as he persecuted the Bogomils and burned their books, viewing them as heretics. Finally, acting at a time when Serbs were facing a choice between Western Christianity and Eastern Christianity, Stefan Nemanja opted for the latter, thereby laying the foundation for the equation of Serbs with Orthodoxy. He eventually abdicated in favor of his second son, and, together with his wife, took monastic vows. Had the cult of Stefan Nemanja been promoted in Serbia in the 1980s and 1990s, that saint's association with state-building and piety might have lent itself to reinforcing forces for political moderation in Serbia.

To put the case in simple terms, what was needed was a king-saint. Sava was a saint but not a king. Dušan was a king but not a saint. Stefan Nemanja was both a king and a saint, and, in this respect, had the most basic credentials for the role as historic hero. But there was an alternative king-saint available - Knez (Prince) Lazar Hrebeljanovic (1329-1389), the son of imperial chancellor Pribac Hrebeljanović. Lazar married Milica Nemanjić, the fourth cousin once removed of Tsar Dušan the Mighty, founded the monastery at Ravanica in 1380, and died on the 
field of battle in 1389. Lazar, it has been said, was visited by an angel on the eve of battle with the Ottoman army and was offered a choice between military victory, winning him an earthly kingdom, and defeat, winning him a martyr's crown and a heavenly kingdom. Lazar, according to a popular interpretation of the myth, chose to die a martyr, thus winning for all Serbs a special status as a heavenly people. Although the way in which the Battle of Kosovo has been remembered and the use made of the myth of 'Tsar Lazar' (as he is commonly called) have changed over the centuries, this myth was more readily adaptable to the Serbian national project associated with Slobodan Milošević (1941-2006) than one focused on Stefan Nemanja. Accordingly, it was Lazar who was touted in the Milošević era as the great Serbian king-saint and national martyr, Lazar whose bones were carried around the towns and villages of Serbia in 1989 in a macabre summoning of the ghosts of the Field of the Blackbirds, and Lazar, whose portrait was carried aloft, next to portraits of Milošević in gatherings in Serbian communities. The epic battle of 28 June 1389 (adjusted for the current Gregorian calendar; 15 June 1389 according to the Julian calendar then in use) was reenacted in the course of the 1990s, in an effort to persuade Serbs to see the battles in their time through the lenses of the past, while, at the height of the struggle in Bosnia-Herzegovina, at a time when Serbian sovereignty in Kosovo had not yet been seriously challenged, Serbs became fond of repeating the slogan, "We shall lose our [lives] but we shall not give up Kosovo." (as quoted by Ivanova, 1999, p. 192).

The choice of Lazar over Stefan Nemanja was symptomatic of the processes underway in Serbia, and worked to reinforce other vehicles of socialization. Lazar the martyr could be avenged; Lazar the saint conveyed a heavenly glow to the Serbian national project. Stefan Nemanja, although he might be recognized as having been an important figure in Serbian history or even, if one wishes, a great king, would not have served so well to rally Serbs for war.

\section{Myths of founding, myths of martyrdom}

In considering national myths, one must differentiate between myths of founding and myths of martyrdom. Myths of founding tell about the founding of the state and typically, though not always, include a notion of entitlement to certain lands. The mythologization of King Stephen of Hungary (c. 975-1038), for example, although originally intended to serve for dynastic legitimation, would also later serve to establish an entitlement of Hungary to the so-called Lands of the Crown of St. Stephen. Myths of martyrdom, by contrast, tell of the heroic sacrifice of a great figure in history - usually in a battle for the country. Myths of martyrdom also involve entitlement, although not to land as such. The martyrdom of Olav the Holy (995-1030) at the Battle of Stiklestad in 1030 may be said to have entitled the Norwegian nation to respect, while the martyrdom of Tsar Lazar, the Serbian prince, on the Field of the Blackbirds in 1389, as already noted, is said to have entitled Serbs to a "heavenly kingdom", although the precise expectations to be associated with that latter entitlement have not always been spelled out. Although every nation has a number of national myths, I suggest that, in the case of European societies, there is usually a dominant national myth involving a medieval king (although, in France, the dominant national myth involves the $15^{\text {th }}$ century warrior-saint, Joan of Arc), and that it makes a difference 
for the content of each nation's nationalism and sense of national purpose whether that dominant myth is a myth of founding or a myth of martyrdom.

In the following text, I shall examine four cases - those of Hungary, England, Norway, and Serbia - arguing that the dominant national myth in the case Hungary is a myth of founding while the dominant national myths in the cases of Norway and Serbia are myths of martyrdom; in England, by contrast, the myth of King Arthur is associated by legend with chivalry, piety, and the quest for the Holy Grail. The kings who figure in the national myths of Norway and Hungary lived in the eleventh century, while the Serbian 'Tsar' Lazar lived in the fourteenth century; King Arthur - and I shall make the case that he did exist - lived and reigned in the sixth century. Three of the four - all except King Arthur - were later canonized. All of them are included in the schoolbooks in use in their respective countries. King Arthur will be contrasted with William the Conqueror, whose victory in the Battle of Hastings in 1066 is often taken as marking the founding of a "new" English state.

\section{Myths of founding and virtue}

For purposes of legitimation, a royal founder should be a man of God - pious, dedicated to the Church, and determined, where necessary, to stamp out 'pagan' faiths. Stephen or István (reigned 1000/1001-1038) was the son of Prince Géza, who reigned from 972 to 997, and Adelaide, a Christian princess of Polish extraction. Although the Christianization of Hungary and the construction of central state power both began under Géza, it is Stephen who has been generally credited with putting the Christian Church on a firm foundation in Hungary and accorded the title of founder of the Hungarian state (Molnar 2001, p. 18). Stephen was crowned King of Hungary in either 1000 or 1001 - sources differ on the exact year of his coronation. But Stephen's claim to the title of founder rests not only on his coronation but, more particularly, on the fact that it was at that time that Hungary first achieved the boundaries which came to be treated as sacrosanct by Hungarians for centuries thereafter ('the Lands of the Crown of St. Stephen') as well as on Stephen's determination to uproot pre-Christian beliefs and practices, a determination backed by force. It was King Stephen who organized the Church in Hungary, setting up the archdiocese of Gran and that of Kalocsa; he founded the monastery of Saints Peter and Paul in Buda, and had churches built in order to promote the spread of Christianity among his people. He also issued edicts mandating severe punishment for blasphemy, among other offenses, and forbade Christians to marry non-Christians (EWTN). He often made donations from the royal treasury to help pilgrims, widows, and orphans, and to support monasteries abroad. Even in marriage he came across as saintly, choosing to marry Gisela, a woman who had originally thought of becoming a nun and who had been educated by St. Wolfgang (Gyorffy 1994, p. 92).

Thietmar, bishop of Merseburg, left a written chronicle of his age, and praised King Stephen for the mercy he showed toward those whom he had defeated in battle, although one may qualify that by pointing out that he showed mercy only toward Christians, not toward those he considered idolatrous. Significantly, when German scribes were brought to Stephen's court, they were instructed to refer to his majesty as "Stephen the Pious" rather than using such other epithets preferred by 
other kings, such as "the invincible" or "the most glorious" or "the magnificent". The widespread tales of his active promotion of Christian charity, even disbursing alms to the poor himself (in disguise) contributed to fashioning a positive image of the king. Shortly after his death, there were reports of people being miraculously healed of various afflictions at his tomb; in 1083, he was canonized by the Vatican and his right hand is maintained as a relic, resting in the Saint Stephen Cathedral in Budapest. His triple role as state-builder, warrior (winning every war he fought), and defender of the Christian faith, together with his reputation for piety, assure this sainted king of the seat of honor in the pantheon of Hungarian heroes. As Gábor Klaniczay (1992, p. 134) has noted, Stephen was the first king to achieve sainthood by some means other than martyrdom.

For the English (and here I do not include the Scots or the Welsh), William the Conqueror provokes variously ambivalence or controversy. When William, Duke of Normandy came to England at the head of an army of between 7,000 and 12,000 men, he claimed to be the legitimate heir of Edward the Confessor, who had reigned from 1042 until 5 January 1066. Edward, canonized in 1161 and regarded as the patron saint of England until 1348, died without issue, and there were immediately three contenders for the throne: Harold Goldwinson, crowned as King of England; King Harald III of Norway; and Duke William of Normandy, who noted that he was related to Edward through the latter's mother, Emma of Normandy. Both Harald of Norway and William of Normandy invaded England to press their claims. The former sent a force into the north of England, but Harold was able to bring an effective force to Stamford Bridge, where his forces crushed the Viking invaders. But William's forces landed at Pevensey in the south three days later. Harold rushed his remaining forces southward to meet William at Hastings on 14 October 1066, and initially seemed to be prevailing. But Harold was killed on the field of battle, possibly by an arrow shot into his eye, and with that Saxon resistance collapsed.

Although what followed has come down as 'the Norman conquest of England', at the time William's claim to the throne was seen as every bit as good as Harold's. Indeed, there was no popular resistance to William. On the contrary, the various earls, thegns, bishops, sheriffs, and other notables were quick to proclaim their loyalty to the new claimant to the throne, hoping thereby to assure their retention of the lands and privileges they had enjoyed. This proved to be naive, however, when, on the pretext that all those who had sworn loyalty to Harold had forfeited all right to their possessions, the Normans confiscated Saxon estates, taking them for themselves (Trevelyan 1942, p. 107). Had William displayed the qualities of mercy and charity so well exemplified by King Stephen of Hungary, he might well have come to embody the spirit of England in myth and status. But, when two earls in the north raised the banner of rebellion, William's vengeance was so cruel, leaving not a single house standing or anyone alive, that his reign easily came to be characterized as 'the Norman yoke', much as Serbs would characterize the Ottoman period in some of their schoolbooks as 'slavery under the Turks'. His virtue thus denied and the legitimacy of his succession contested, William I might be considered the founder of the (new) English state in some sense, but it would be difficult at best to imagine the memory of his reign being recalled either to inspire the English or to mobilize them. For the purpose of inspiration, another king had to be found. 
That king was King Arthur, a legendary figure whose existence has been disputed but who may have led the Celts in an effort to stave off invading Angles and Saxons in the late fifth and early sixth centuries. As the Anglo-Saxons advanced, the Celts were pushed back into Cornwall and Wales. The former called their realm England, while the Celts driven back into the region today known as Wales were called 'Welsh' (from 'weala' meaning foreigners) by the Anglo-Saxons. These Celts called themselves 'Cymry' (fellow countrymen) and their country 'Cymru'. This has a bearing insofar as the earliest references to King Arthur occur not in English chronicles but in Welsh ones (Caerleon Net):

In the following centuries, it was the French who seemed to be the most interested in the Arthurian legends. The French poet Maistre Wace retold the story of Arthur in 1155, adding the Round Table; Chrétien de Troyes, another French writer, penned five stories about the king between 1160 and 1180, developing the theme of chivalry; and Robert de Boron (also spelled Bouron), a Burgundian knight and French poet of the late $12^{\text {th }}$ and early $13^{\text {th }}$ century, added the notion that King Arthur and his knights had been on a quest for the Holy Grail.25 Finally, in the late fifteenth century, Sir Thomas Malory gave the Arthurian legend its quintessential expression in his book, Le Morte D'Arthur, published by William Caxton in 1485.

But King Arthur had taken hold of the imagination of the English long before Sir Thomas Malory's saga. Indeed, by the early nineteenth century there had appeared references to the legend that the king lay sleeping in a cave somewhere in Britain, to be awakened at a time of national crisis (Simpson 1986, p. 206). In some versions, all of the king's knights were also sleeping in the same cave, ready to reveal themselves in Britain's hour of need. The original Arthur was surely a real king. The legend of St. Cadocus describes King Arthur as a crude and rough-hewn border chieftain, quite unlike the Arthur of legend (Loomis 1933, p. 478). This alternative portrait of the Celtic king obviously gives Arthur no special credit, but it may be closer to the historical Arthur. Then there is the matter of Arthur's tomb, said to be located at Glastonbury Abbey, which in the 500s had been a Celtic Christian shrine - a fit place to bury a Celtic king (for discussion see Nitze 1934; Carley 2001). Certainly, Mary Williams (1962, p. 73), a scholar specializing in Arthurania, concluded that King Arthur was a real person. But the very fact that his existence has been disputed arguably lends special potency to the legend of Arthur who is, thus, shrouded in mystery and who, if we choose to consider him fictional (as some authors do), could be anything we want him to be.

In the early twelfth century, Cornishmen and Welsh, descendants of the Celts, still nurtured the belief and hope that Arthur would return, refusing to believe that he had actually died more than half a millennium earlier. Later, the legend became part of English lore, so that, in 1278, King Edward I (reigned 1272-1307) ordered the ceremonial reburial of the exhumed last remains

25 The Holy Grail is sometimes understood to be the chalice from which Jesus of Nazareth drank at the famed Last Supper and sometimes understood to be the chalice which captured his blood while he was nailed to the cross. Either way, the chalice was thought to have magical and beneficent powers. Robert de Boron linked the two versions by claiming that Joseph of Arimathea used the chalice from the Last Supper to catch the last drops of blood from Jesus' body on the cross. For further discussion of the legend of the Holy Grail, see John B. Marino, The Grail legend in modern literature (Cambridge \& Rochester, N.Y.: D. S. Brewer, 2004). 
of, it was said, King Arthur at the high altar of Glastonbury Abbey. An Order of the Knights of the Round Table had also come into existence by the fourteenth century - though said to be 'ancient' - and in 1349 King Edward III (reigned 1327-1377) transferred the Order to Windsor Castle, redesignating it the Most Noble Order of the Garter. Still later, in the reign of Elizabeth I (reigned 1558-1603), a society of archers existed, calling themselves 'the Knights of the Round Table'. Legends of Arthur proliferated over the centuries, in one version having him killing an evil Black Witch and, in another, casting him as a giant.

But to return to the twelfth century, King Henry I (reigned 1100-1135), son of William the Conqueror, started his reign by having to fight wars to retain control of his realm. In this situation, the king stood in need of a heroic ancestor, someone whose glory could be compared, say, to that of Charlemagne. It was the genius of Geoffrey of Monmouth (c.1095-c.1155) to recognize how to meet this need, as Gordon Hall Gerould has pointed out. Indeed, the composition of Geoffrey's History was consciously designed to demonstrate that King Arthur was not only a greater king than Charlemagne but also more ancient (thus reinforcing his credentials as a worthy ancestor) (Gerould 1927). And while he was not canonized, Arthur's alleged commitment to the virtues of chivalry and his reputed quest for the Holy Grail provided adequate compensation.

\section{Myths of martyrdom - Norway}

An alternative to myths of founding are myths of martyrdom, in which the claim to sainthood - and thus also to political legitimacy - is often more firmly established. The national martyr dies for the sake of the nation and, as such, embodies the nation. Within this broad parameter, however, there is room for considerable variation. Jan Hus (1370-1415) of Bohemia, a religious reformer but no king, was burned at the stake on charges of heresy but, in death, inspired the religio-patriotic Taborites who saw themselves as fighting for God; today, Hus is considered the national saint. Rodrigo Diaz de Vivar (1040-1099), better known as 'El Cid', was a Castilian nobleman and military leader who fought the Moors in Spain and eventually carved out his own kingdom; although he died of natural causes, legend has it that, after his death, his body was strapped onto his horse and sent into battle, so that El Cid won his final battle while actually dead and thereby winning him an honorary, if curious, place among martyrs for the nation. Neither Jan Hus nor El Cid was canonized, but Joan of Arc (1412-1431), an illiterate farmer's daughter who led the French army to victory against the English only to be captured in 1430 and burned at the stake by the English on trumped up charges of heresy, was accorded this honor in 1920.

Among those medieval kings remembered as martyrs are King Olav the Holy of Norway and Prince Lazar of Serbia - both of them canonized. Both died in battle in a struggle over land. Both were credited with posthumous miracles. Both are still remembered today in their respective nations and honored as national heroes. But where the memory of Lazar today evokes, if anything, a sense of national tragedy and, in the context of Kosovo's impending independence, also a bitter sense of déjà vu, Olav den hellige (Olav the holy) is remembered by ordinary Norwegians either with reverence, as having completed the process of the Christianization of their country, or without thinking at all about Olav's place in history. 
Even so, historical and scholarly accounts of Olav differ widely. As Father Olav Müller notes, for some authors Olav is "a brutal psychopath", but for others, "a bloodless saint like an angel." (Muller 1993). The historical Olav Haraldsson was born in approximately 990 and claimed to be a descendant of Harald Hårfagre (Harald the Fair-haired), who had died in 933. At a young age - indeed, perhaps when he was no older than 12 - he assembled a Viking crew and set out on a voyage of pillage and plunder. Although Olav Tryggvason, who reigned as King of Denmark and part of southern Norway from 995 to 1000, had begun the forcible Christianization of Norway, polytheism still had a strong presence in the country at the beginning of the eleventh century. Olav Haraldsson himself was born into the ancient religion and, in his day, members of royal families generally claimed to be descended from the gods Frøy and/or Odin. Like other kings in medieval times (such as King Arthur, at least according to legend), Olav possessed a very special sword which, in his case, was a symbol of his descent from the gods; the sword was regarded as possessing supernatural powers and thereby endowing the person who wielded it with the assurance of victory in battle. Olav and his Vikings raided villages along the English coast for three years and, in 1009, attacked London, where they tore down London bridge. Two years later, he took part in the sack of Canterbury; the English king, Ethelred, agreed to pay a ransom so that Olav and his companions would leave his country in peace. With the ransom in their hold, Olav's Vikings sailed to Normandy, where Olav he was baptized a Christian.

Returning to Norway in 1015, Olav succeeded within a short time in being accepted as king in most of southeastern Norway. Winning a naval battle in the spring of 1016, he added the southwest and the 0slo fjord area to his kingdom; and in summer 1016, he came to Trondheim where he was accepted as king there too (Viking). In the following months, he succeeded in establishing his rule over the entire country, and, fired by his new faith, decided to impose Christianity on his people. This was done at the point of the sword (Timonen 1996). He also abolished laws inconsistent with Christian teaching, which he made the foundation for a new legal system. The changes to the laws were unpopular with both the common people and the local nobles, whose status was adversely affected, and Olav assigned årlmenn (men from his royal guard) to keep watch over the local chiefs. Meanwhile, King Knut of Denmark and England (reigned in England, 1016-1035, and in Denmark, 1018-1035) - known in English history as King Canute the Great - took note of the growing discontent among Norwegians and sent gifts of treasure to the local chiefs in Norway, in hopes of winning their allegiance. He also promised them to restore their old privileges if they accepted him as their monarch. Knut's overtures were successful, and, when he arrived in Norway in 1028 with a large fleet, Olav had to flee the country. He took refuge in Kiev, as the guest of his brother-in-law, Grand Duke Jaroslav. After securing control in Norway, Knut returned to England, leaving Håkon Jarl to govern as his viceroy.

In 1029, Håkon Jarl drowned and, upon hearing the news, Olav decided to return to Norway in an attempt to regain his throne. According to Snorri Sturloson (1178-1241), the Icelandic mythographer and poet, Olav assembled a force of about 3,600 men for this venture, augmenting this force enroute until he led an army of 7,000 men. At Stikestad on 29 July 1030, he was met by forces commanded by Hårek from Tjøtta, Tore Hund from Bjarkøy, and Kalf Arnason, who had 
previously served under Olav's command. Olav received three severe blows to the head and died on the field of battle; his army lost, and his body was removed and buried secretly in Trondheim.

Legends quickly grew about Olav. According to the Saga of Legends, his body rose out of the ground just one year and five days after it had been buried, and had to be reinterred. His body allegedly rose a second time nine nights later. At this point - so the story goes - Bishop Grimkjell and King Svein (Knut's son and the vassal king of Norway, 1030-1035) ordered that a strand of hair be plucked from his beard so that it might be burned. But when the hair was placed in consecrated fire, it did not burn. Soon thereafter, there were reports of miracles taking place at his tomb (Henriksen 1985). The story also began to circulate that, on the eve of the Battle of Stiklestad, Olav had had a dream in which he had seen a ladder leading up to heaven and had climbed up the ladder, where he could see heaven before his eyes. When he told his countryman Finn Arnesson of the dream, Finn told the king that this was a bad omen, signifying that the king would die in battle. Rather than being disheartened at this prospect, Olav saw this as the fruit of his "yearning for the crown of martyrdom," as the Passio Olavi, a medieval text from Norway written in Latin, records. Moreover, although he took his pagan sword with him into battle, upon being wounded above the left knee, Olav hurled the sword far away - according to Snorri's account - thus giving up the fight and giving his soul up to God. Henriksen comments cautiously, "If that was so - and I am certainly not declaring that it definitely was - then Olav's throwing away of Olav Geirstad-alv's sword signified his ultimate conversion and his final surrender to the God of Christianity. Furthermore, in the eyes of the Church that one act could have vindicated him of his former violence and harshness" - some of which was, in any event, committed in order to propagate the Christian faith.

The cult of the new saint spread across Europe, gaining an early foothold in England, where, in the early years, the cult of St. Olav was reflected in the dedication of a number of churches to his memory (Coupland 1998, pp. 7-9). From around 1050 until 1537, when the Reformation came to Norway, pilgrims came to Trondheim from all over Europe. For those making the journey, the pilgrimage had sacerdotal significance, even if no miraculous cures resulted. For the Church, the growing myth of St. Olav made a significant contribution to strengthening Christianity among the Norwegians. For the state, the legend strengthened the hand of future kings of Norway Emblem et al.1997, p. 63). St. Olav, described as a combination of apostle and martyr, came to be regarded as the national saint of Norway. In a recent hagiographic essay, we find the following judgment passed on the dead king:

The Battle of Stiklestad must have appeared as the definitive downfall of a failed king. However, the tables were turned: The two main objectives Olav had been fighting for, uniting and christening Norway, gained their final victory through his death as a martyr...0lav became a saint deeply loved by the people because he appealed to more or less all groups. He was the champion of peasants and sailors, the patron saint of traveling merchants and city dwellers, defender of the monarchy, and the protector of the needy. He was a hero after the fashion of the times, a knight of the faith as if springing from the imagery of the stories of the knights. (Langset 1998, pp. 8-9). 


\section{Myths of martyrdom - Serbia}

The preceding discussion is quite sufficient to show that the mythologization of a dead king is by no means unique to Serbia. Moreover, in the case of Norway, we have a king-saint who, like Lazar, is said to have had a dream on the eve of battle in which he was given a vision of heaven, to have freely chosen martyrdom, to have died on the field of battle, and to have in some sense achieved 'victory' through defeat in battle. Yet, in spite of these striking parallels, the uses to which the legend of Prince Lazar and the Battle of Kosovo have ended up being put in Serbia are quite different from the uses made of the legend of King Olav and the Battle of Stiklestad, let alone the legends of King Stephen or King Arthur.

The armies which met on the Field of the Blackbirds on 28 June 1389 were multiethnic. Sultan Murad I (reigned 1359-1389), nicknamed Hüdavendigar or 'the God-like One', commanded a force which included Greeks, Bulgarians, and Albanians. Prince Lazar's army consisted of Serbs, Croats, Albanians, and Bulgarians, among others (Temperley 1969, p. 100). Murad's purpose in striking into Serbia was to bring that state under his scepter, initially as a vassal state and later as a fully incorporated province of the 0ttoman empire. Lazar's army was seriously outnumbered. According to the most reliable accounts, Murad's army numbered about 27-30,000 troops, while Lazar's numbered only 15-20,000 (Malcom 1998, p. 64). There are no eye-witness accounts, but, in 1601, a Ragusan monk, Mavro Orbini, published a work of history in which he named Vuk Branković, one of Lazar's sons-in-law, as a traitor, although the author seems to have mixed up Vuk Branković with Đurađ Branković, Vuk's son, who informed the sultan of that time of the movements of troops commanded by the Transylvanian nobleman János Hunyadi on the eve of the second Battle of Kosovo (1448). The outcome of the battle of 1389 seemed, on the surface, ambiguous, however, even if Serbia would now function as an 0ttoman vassal for the next 70 years. Both Lazar and Murad died on the battlefield, and both armies withdrew. One of the earliest reports of the battle, in a letter sent by King Tvrtko of Bosnia - who had not actually been in Kosovo himself (Mihajlčić 1989, p. 47) - to the Senate of the Dalmatian city of Trogir on 1 August 1389, claimed that the Christian army had won a great victory over the Ottomans; the death of the sultan at the hands of a Christian assassin seemed to support this representation (Emmert 1991, p. 22). Strikingly, in Ottoman Serbia - according to Miodrag Popović - the local population did not give the legend of the Battle of Kosovo an interpretation unfavorable or hostile to the Ottoman Turks. On the contrary, Serbia's culture in the sixteenth and seventeenth centuries was 'Turkophilic', with Serbs enjoying religious autonomy and freedom of worship, and facing a lighter burden of feudal duties than their counterparts elsewhere in Europe (quoted by Greenawalt 2001, p. 53).

Between 1841 and 1862, Vuk Stefanović Karadžić (1787-1864), the Serb orthographer and language reformer, published four volumes of Serbian National Songs, among which a few treat of Kosovo. In one of these we find Sultan Murad, already dying from his wounds, giving the following command to his vezirs and other aides:

Turks, brothers, lale [lower court officials] and vezirs,

I die, and the empire falls to you!

So that your empire may endure long, 


\section{Securitity}

Do not be cruel to the flock,

But be very good to the flock.

Let the head tax be 15 dinars;

Even let it be 30 dinars.

But do not levy fines or special taxes.

Do not impose grief upon the flock.

Do not touch their church;

Neither its law nor its observation.

Do not take revenge upon the flock,

Just because Miloš has cut me.

That was military fortune...

You must not chase the flock away

Into the forests so that they will abhor you,

But watch over the flock as if they were your own sons;

In that way the empire will last you long.

But if you begin to oppress the flock,

\section{You will then lose the empire (as quoted in Greenawalt 2001).}

In this verse, the sultan is recalled as a charitable and wise ruler, who wishes the future Serbian subjects of the Ottoman empire well. For Serbs reading this poem, the Battle of Kosovo emerges not as a crime to be avenged but as the moment when the sultan offered a pledge, albeit in his last breath, to which Serbs could hold his heirs. Moreover, in Karadžić's version, the sultan proposes that his assassin, Miloš Kobilić, be buried next to him; Kobilić then protests that he is unworthy to be buried next to an emperor and proposes rather that sultan and prince be buried side by side, recognizing their equality, and that he himself be buried at their feet. According to Karadžić, the sultan granted his assassin this request.

In another poem, Karadžić has the prophet Elijah visit Prince Lazar on the eve of battle and offer him a choice between a heavenly kingdom and an earthly one (Greenawalt 2001, p. 57). In an alternate version of the story - the better known version of the legend - it is an angel who visits Lazar in a dream, but in both versions Lazar chooses to die a martyr's death, much as King Olav is said to have done, and in this way secured a heavenly kingdom for himself and for Serbia. Greenawalt suggests that what has become the traditional interpretation of this episode may be at variance with the intentions of those who first circulated the legend of the heavenly vision and certainly with Vuk Karadžić's intentions. Greenawalt stresses that Lazar's choice of a heavenly kingdom cannot be seen as a myth of founding of a Serbian state but rather lends itself to legitimating Ottoman sovereignty in Serbia, recognizing that, in Ottoman-era Serbia, the 'heavenly kingdom' - the Serbian Orthodox Church - enjoyed considerable autonomy and freedom.

I have already mentioned King Tvrtko's early interpretation of the battle as a victory for Christendom. In the period immediately following the death of the prince and his widow's acceptance of a vassal relationship with Istanbul the following year, Serbs were overcome with despair. Thomas Emmert speculates that it was in hopes of combating this mood and in order to instill hope in Serbs that monastic figures now took up the pen, eulogizing the fallen prince. One of the best known poems from this period is Patriarch Danilo III's Slovo o Knezu Lazaru, composed in 1392. 
In Danilo's rendition, the prince assembled his forces before leading them into battle, and offered them these words of encouragement:

\begin{abstract}
....if the sword, if wounds, or if the darkness of death comes to us, we accept it sweetly for Christ and for the godliness of the homeland. It is better to die in battle than to live in shame. Better it is for us to accept death from the sword in battle than to offer our shoulders to the enemy. We have lived a long time for the world; in the end we seek to accept the martyr's struggle and to live forever in heaven. We call ourselves Christian soldiers, martyrs for godliness to be recorded in the book of life (quoted in Emmert).
\end{abstract}

In the anonymous Pohvalno slovo knezu Lazaru, the fallen prince is compared to Christ himself, a comparison hinted in Adam Stefanović's painting, "The Feast of the Prince Lazar", dating from the 1870s. In this painting, Lazar and his lords are arrayed around the supper table in a pattern unmistakably reminiscent of Christ's Last Supper, with a shaft of light illuminating Lazar as if in a divine glow, while leaving most of the rest of his entourage in the shadows. ${ }^{26}$ The comparison with Christ is also implicit in the poem, "The Finding of Prince Lazar's Head", which records that, after Lazar was beheaded in battle, his head was dropped into a well; forty years passed before someone found the head, at which point Lazar's headless body also appeared, the head miraculously joined the head, and Lazar reappeared whole in body as he had been before death. Commenting on this poem, Z. D. Zimmerman suggested that the decapitation of Lazar served as a metaphor for the decapitation of Serbia, with the head symbolizing the spirit of the nation and the body symbolizing the nation itself; on this interpretation, the resurrection of Lazar brought about by the reunification of head and body prophesied the eventual resurrection of the Serbian nation.

The decapitation is treated rather differently in a panegyric song, dating from the sixteenth century, which claimed that, while Lazar's body remained in the ground, his head was seen floating by itself over the Field of the Blackbirds (Antonijevic 1991). As with other king-saints, amazing stories were connected with his earthly remains, which were said to possess miraculous powers. It was also claimed that Prince Lazar's bones, said to have been preserved in a monastery at Ravanica, were in some sense still alive or, in an alternative account, that God had preserved Lazar's last remains from decay, in a sure sign of his sainthood. Again, as with other king-saints, the dead prince was portrayed in early writings as a pious man of God. The cult even carried over into the realm of horticulture, where the belief became widespread among Serbs that every peony that grew on the Field of the Blackbirds sprouted out of the blood of a fallen Serb soldier.

The earliest Serbian writings about the battle focused on establishing the legitimacy of Lazar's kingship and his status as a martyr for the faith; indeed, it is sometimes recorded that the Serbian Orthodox Church canonized him soon after his death. Like so much else connected with the cult of Lazar, however, even this is disputed. Đorđe Trifunović, for example, claims that Lazar became a saint without any official act of canonization; the renowned theologian and church historian

26 The painting is reproduced as an appendix to Ljubica D. Popovich, "The Battle of Kosovo (1389) and Battle Themes in Serbian Art", in Vucinich and Emmert (eds.), Kosovo: Legacy of a Medieval Battle, p. 287. 
Lazar Mirković is of the same opinion, grounding the claim of sainthood for Lazar in the Orthodox tradition that, for a martyr, no specific ecclesiastical action is necessary because sainthood is already achieved by virtue of martrydom. Others hold that the Church did canonize Lazar officially, even if the exact date of canonization cannot be determined. However, as Rade Mihalǰcić notes, what lies at the heart of the dispute as to how Lazar became a saint is the question as to whether the cult of Lazar was organized by Church leaders or arose spontaneously (Mihaljčić 2001).

Meanwhile, the ostensibly ambiguous outcome of the battle - as already mentioned, Serbs did not lose their kingdom until 1459 - allowed another debate, about who had won and who had lost, to continue. Radojčić, for example, writing as recently as 1955 and citing the anonymous Prološko žitije kneza Lazara, claimed that the earliest texts suggested that the Serbian side had won a military victory at Kosovo, while Danilo III, in his aforementioned Slovo, judged that neither side had won a victory on that day (Emmert 1991, p. 26-27). Moreover, while later texts would claim that Miloš Kobilić - described as Lazar's other son-in-law but possibly a literary invention - had assassinated the sultan in his tent, Danilo's account implied that the Ottoman sultan was killed in battle. It was only later that the story of the assassination was woven into the legend; this version of events first appeared in an account by Constantine the Philosopher, a fifteenth century Bulgarian historian. But it was still later, in 1497, that the presumed assassin was given a name - in Konstantin Mihailović's Memoirs of a Janissary.

On this point, it is of interest that, among the earliest reports of the battle, we find an account alleging that Sultan Murad was killed by Prince Lazar himself at the height of battle (and hence, not assassinated by Kobilić), while other writings which are considered to be associated with the cult of Lazar claim that it was the other way around - that it was Sultan Murad who personally killed Prince Lazar. As Rade Mihaljčić (2005, p. 167) points out, "Death at the hands of a pagan tsar is of particular importance for the prince's canonization for it could thus be emphasized that the prince died in the same way as the early Christian martyrs." But the version of the legend which has acquired a status as the semi-official version of the state, insofar as it is the version given in the schoolbooks, is that the sultan was assassinated by Kobilic, seen thus as a Serbian hero (Mihaljčić 2005).

Perhaps the first detailed account of the battle came in 1512, in the work of the Turkish writer, Mehmed Neşri. The Turk was given to exaggeration and invention, claiming that Lazar's army numbered 500,000 troops - a number far in excess of what any medieval prince could muster - and further claiming, contrary to the facts, that Lazar's forces were more than twice as great as Murad's. Moreover, in Neşri's account, while Murad and his men prayed until dawn, Lazar and his troops spent the night before the battle getting drunk. Just as the legend alleging that Lazar had been visited by St. Elijah or by an angel served to lend the Serbian side a heavenly sanction, so too did this alternative account serve to suggest that the Turkish side enjoyed divine favor. Many of the details of the story which have come down to us entered into the legend in the course of the sixteenth century, so that the Kosovo myth "was well developed by the end of the sixteenth century and beginning of the seventeenth century, but assumed its definitive form 
in the History of the Battle of Kosovo," an anonymous work published at the beginning of the eighteenth century (Redjep 1991).

Then, in 1847, the appearance of the epic poem, The Mountain Wreath, written by Petar Petrović Njegoš, the Prince-Bishop of Montenegro, gave the legend of Kosovo a much darker interpretation, describing it as a defeat for the Serbian kingdom and linking that defeat to God's punishment for the Serbs' alleged disloyalty. Although the poem had, as its main theme, the conflict between Christians and Muslims in Kosovo, it ranged beyond the borders of Kosovo and spewed out intolerance for Muslims. For Njegoš, the heavenly kingdom is not the autonomous Church but is to be won by taking up the sword against Serbs who converted to Islam, who thus 'betrayed' the nation. Recasting Kobilić as Obilić - in reflection of an eighteenth century editing of the original name (Corović 2004, p. 253) - Njegoš describes a collective dream shared by Danilo and the Serb chieftains of that day. In this unlikely shared vision, the dreams imagine "a resplendent Miloš Obilić flying above them on a white horse" and take an oath to massacre all converts who will not return to Christianity. With this, Kobilić ceases to be the national patriot who shows his loyalty to his prince by assassinating the sultan and becomes instead "the martyr of national purity, the genocidal Christ." (Greenwalt 2001, p. 61).

\section{Lazar in the camp of Serb nationalists}

In spite of the multiple variants and alternative accounts of the Battle of Kosovo which had been offered over the centuries, by the mid-twentieth century, the dominant version was one which stressed not only that the battle represented a national tragedy for Serbia but also that it signified symbolically, if not also in historical terms, "the disastrous end of the glorious mediaeval era of Serbia and the beginning of a long lasting slavery under the 'Turkish yoke'." (Prošić-Dvornić 2000, p. 170). The collaborationist regime of Milan Nedić (1941-1944) played a role in this process, by promoting the myth of Lazar's choice of the heavenly kingdom, on the eve of battle, to a central place in Serbian national mythology (Ristovic 2001, p. 65). The Battle of Kosovo, thus, came to symbolize the spirit of resistance, hostility to Muslims, and, by forgetting the presence of Christian Albanian soldiers in Prince Lazar's army, also the supposedly 'eternal' struggle between Serb and Albanian.

This is not an invocation of Prince Lazar, the pious man who chose martyrdom and a heavenly kingdom over an earthly kingdom, but a call for an avenging angel who would take that entitlement to a heavenly kingdom and convert it into an earthly kingdom. It was, of course, Slobodan Milošević, president of the League of Communists of Serbia from 1987 and president of the Republic of Serbia beginning in 1989, who answered that call. The cult of Prince Lazar and of the Battle of Kosovo was stepped up almost immediately after Milošević assumed power. Book publishers responded to the call with books about Kosovo, folk singers responded with sentimental songs about Kosovo, there was even a perfume manufacturer who obliged by producing a new fragrance marketed as 'Miss 1389'. While the press published a series of interviews, articles, and historical retrospectives focusing on the sufferings of the Serbian people during World War Two (but never talking about the sufferings of the other peoples of Yugoslavia during that fratricidal conflict), 
as well as on other sufferings of the Serbs, it was Kosovo which provided the unifying myth and the banner under which Serbs could rally. Thus, too, in the famous Memorandum drawn up by members of the Serbian Academy of Sciences and Art, Kosovo was given a special emphasis, insofar as the claim was now registered that the Albanians of Kosovo were perpetuating nothing less than genocide in this heartland of medieval Serbia. Orthodox clerics had been saying even before Milošević came to power that Kosovo was 'the Serbian Jerusalem' but, before Milošević's seizure of power, this claim was a form of dissent from the official communist line. Now this claim was endorsed by the regime.

The construction of a specific collective memory of the battle of Kosovo was useful to the regime because the themes of bitterness, injustice, resentment, and righteous anger evoked by that myth were useful to the mobilization for war. If Serbs could see themselves as victims, then they would feel justified in exacting what they would consider revenge. Ironically, in the early 1990s, although the myth of Kosovo was used to justify the suppression of the considerable autonomy which had been enjoyed by provincial authorities in Kosovo, it was also harnessed to the project of mobilizing Serbs for a war to redraw the boundaries with Croatia and Bosnia-Herzegovina, on the specious argument that 'all Serbs should live in one state' - a claim registered by both novelist-turned-politician Dobrica Ćosić and by Milošević himself. It was, moreover, Cosić who handed the Serbian leader a 'magic sword' with his oft-repeated claim that Serbs had never lost a war. The Albanians understood the role of the cult of St. Lazar. Thus, when, in fact, Serbia lost first the War of Yugoslav Succession and then its war with NATO over Kosovo, Albanian demonstrators took their revenge on the Serbs by pulling down the statue of Prince Lazar in Gnjilane in July 1999, thereby assaulting the cult of Lazar symbolically (KFOR 1999). Kosovo remained high on the agenda of Vojislav Koštunica, who became President of Yugoslavia in October 2000 and who served as Prime Minister of Serbia from March 2004 to July 2008. After 9/11 and the declaration of a 'war on terror' by US President George W. Bush, Belgrade enjoyed presenting itself as a natural ally in the fight against Islamic extremism and, in late 2003, even sent a contingent of troops to fight alongside American forces against the Taliban in Afghanistan (New York Times 2003). Although the international community supported the endeavor of Kosovo's Albanians to declare an independent state and separate from Serbia, Koštunica remained firmly opposed, repeatedly trying to have the issue referred to the UN Security Council where Russia would veto any endorsement of independence for the Albanians of Kosovo. One could even imagine Koštunica as Prince Lazar reincarnate, fighting a battle he knew he would lose, but welcoming the status of martyr for the Serbian cause.

On 28 June 2007, hundreds of Serbs gathered at the site of the historic battle to mark the anniversary. In a statement given to the daily newspaper Politika on that occasion, Koštunica said that a new battle was being waged for control of Kosovo - this time, in his view, between the USA and Serbia. The then-prime minister offered that, in his view, "the key question is whether force will prevail over justice in the new Kosovo battle." (as quotted by Serbianna 2007). At the same time, Patriarch Pavle, head of the Serbian Orthodox Church, warning that 'black clouds' were hanging over Kosovo, recalled once again the role of 'Tsar' Lazar in leading the Serbs in the 
original Battle of Kosovo, and stressed that the Serbs were protecting not just their own interests in Kosovo, but in fact "the sanctities of enlightened mankind." (Ibid.)

\section{Conclusion}

I have considered at some length the myths woven around four dead kings - Stephen of Hungary, Arthur of the Celts, Olav of Norway, and Lazar of Serbia - making passing references also to El Cid and Joan of Arc. Grand Prince Alexander Nevsky (1221-1263) of Russia, who defeated the Livonian Knights in the historic Battle on Lake Chudskoe on 5 April 1242, who was canonized in 1547 by the Russian Orthodox Church, and who was celebrated in Sergei Eisenstein's 1938 film for which Sergei Prokofiev composed the score, certainly belongs in this company. Now, what is striking is that those individuals who elevated to the status of mythic symbols of the nation tend to be kings or princes or at least, in the case of El Cid, a nobleman (indeed, all except Jan Hus and Joan of Arc), warriors (all except Jan Hus, although the warrior image is not central in the cases of Kings Stephen and Arthur), and saints (all except El Cid and King Arthur). Moreover, Prince Lazar and King Olav, like El Cid, Jan Hus, and Joan of Arc, are considered to have been martyrs.

I posed the question earlier, what if Belgrade had promoted a cult of Stefan Nemanja (or St. Simeon the Myrrh-flowing, as he is also known) instead of the cult of Prince-Saint Lazar. Certainly, such a choice would have been available to Belgrade and, had the Belgrade authorities been pursuing different goals in the years following 1987, a cult of St. Simeon/Stefan Nemanja might have made a great deal of sense. But there are at least two reasons why this did not happen. The first is already implicit in what I have just written, viz., that for Belgrade's ambitions in the Milošević era the cult of Lazar was the better choice. The second reason is to be found in the more distant past, and that is that the Church had historically invested vastly more energy in promoting the cult of Lazar than it did on behalf of Stefan Nemanja. And it is for both of these reasons that the cult of Prince-Saint Lazar proved to be so potent in Serbian history, and that Serbia is still affected by Lazar's legacy.

Myths connect the nation with its sense of identity; they may even make a contribution to defining that identity. Myths are, among other things, vehicles serving to create collective memory, and those chosen to serve as the heroes and villains in those passion plays also serve to define what will be considered Good and Evil for the nation. Thus, as Njegoš reworked the collective memory, it was Serb converts to Islam who were the chief villains, with Islam cast as the great Evil for the Serbian nation. Against this, those who kill Muslims may be seen, at least by Njegoš, as 'heroes' while the religious and national unity (homogeneity) becomes the greatest Good. If we may say that people are 'grounded' when they are in touch with the values of their community - which is not to suggest that it is necessarily always good to accept the values which happen to be dominant in one's environment - then the national identity may also be understood to embrace the set of values which are determinative for the community.

National identity shifts and evolves over time, as values evolve and change, and is always open to political manipulation. And when elites want to manipulate the values of the community, the national myth often figures as one of the keys to accomplish that task. 


\section{References}

1. Dragislav Antonijević (1991), "Der Kult des Fürsten Lazar in der Folkloretradition", in in Đuretić V. and Tasić N. (ed.), Kosovska bitka 1389. godine i njene posledice : međunarodni simpozijum, Beograd: SANU.

2. Caerleon Net "King Arthur - How the Legend Developed", in Caerleon Net, at http:// www.caerleon.net/history/arthur/page3.htm

3. Carley James P. (ed.) (2001), Glastonbury Abbey and the Arthurian Tradition, Cambridge $\&$ Rochester, N.Y.; D. S. Brewer.

4. Coupland Simon (1998), A saint for all nations: The cult of Saint Olaf outside Norway, Trondheim: Nidaros Domkirkes Restaureringsarbeideres forlag.

5. Cirković Sima (2005), Istorija za II razred gimnazije prirodno-matematičkog smera, $8^{\text {th }}$ ed. (Belgrade: Zavod za udžbenike i nastavna sredstva.

6. Gerould Gordon Hall (1927), "King Arthur and Politics", Speculum, 2(1).

7. Corović Vladimir (2004), Istorija Srba (Bograd: I. P. Ivanišević \& I. P. Logos Art.

8. Coodich Michael (1975), "The Politics of Canonization in the Thirteenth Century: Lay and Mendicant Saints", Church History, (44)3.

9. Greenwalt Alexander (2001), "Kosovo Myths: Karadžić, Njegoš, and the Transformation of Serb Memory", Spaces of identity, no. 3.

10. Györffy György (1994), King Saint Stephen of Hungary, Boulder, Colo.: Social Science Monographs.

11. Emblem Terje, Libæk Ivar, and Øivind Stenersen (1997), Norge 1: Norges Historie før 1850, 0slo: J. W. Cappelens Forlag.

12. Emmert Thomas A. (1992), "Prologue to Kosovo: The Era of Prince Lazar", available at http://www.kosovo.net/sk/history/dorich_kosovo/kosovo10.htm.

13. Emmert Thomas A. (1991), "The Battle of Kosovo: Early Reports of Victory and Defeat", in Wayne S. Vucinich and Thomas A. Emmert (eds.), Kosovo: Legacy of a Medieval Battle, Minneapolis: Minnesota Mediterranean and East European Monographs.

14. EWTN Global Catholic Network, "Saint Stephen Confessor, King of Hungary - 975-1038", at https://www.ewtn.com/catholicism/library/saint-stephen-confessor-king-of-hungary-5845.

15. Henriksen Vera (1985), Hellig Olav, Oslo: Aschehoug.

16. Ivanova Radost (1999), "Once More About the Kosovo Epos and its Utilisation", Ethnologia Balkanica, Vol. 3.

17. "KFOR Press Statement, Delivered by Major Jan Joosten, KFOR spokesman", in KFOR Press Statements (27 July 1999), at www.nato.int/kosovo/press/1999/k990727a.htm

18. Klaniczay Gábor (2002), Holy Rulers and Blessed Princesses: Dynastic Cults in Medieval Central Europe, Cambridge: Cambridge University Press.

19. Langslet Lars Roar (1998), "The Saint King". In Stein Thue (ed.), On the Pilgrim Way to Trondheim, Trondheim: Tapir.

20. Loomis C. Grant (1933), "King Arthur and the Saints", Speculum, 8(4).

21. Malcolm Noel (1998), Kosovo: A Short History, London: Macmillan, 1998.

22. Marino John B. (2004), The Grail legend in modern literature, Cambridge \& Rochester, N.Y.: D. S. Brewer. 
23. McKenna J. W. (1970), "Popular Canonization as Political Propaganda: The Cult ofArchbishop Scrope", Speculum, 45(4).

24. Mihajlčić Rade (1989), The Battle of Kosovo in History and in Popular Tradition, Belgrade: BICZ.

25. Rade Mihaljčić (2001), Lazar Hrebeljanović - Istorija, kult, predanje (Belgrade: Srpska školska knjiga \& Knowledge Press.

26. Rade Mihaljčić (2005), Istorija za 6. razred osnovne škole, 4th ed. Beograd: Zavod za udžbenike i nastavna sredstva.

27. Molnár Miklós (2001), A Concise History of Hungary, Cambridge: Cambridge University Press.

28. Müller Father Olav, "Saint Olav - King of Norway" (1993), reproduced at http://www. katolsk.no/biografier/historisk/olav/english.

29. Nitze W. A. (1934), "The Exhumation of King Arthur at Glastonbury", Speculum, 9(4).

30. "Olav Haraldsson - Olav the Stout - Olav the Saint", at www.viking.no/e/people/st.olav/ index.html.

31. Popovich Ljubica D., "The Battle of Kosovo (1389) and Battle Themes in Serbian Art" (1991). In Vucinich W. and Emmert T. (eds.), Kosovo: Legacy of a Medieval Battle, Minneapolis: University of Minnesota.

32. Prošić-Dvornić Mirjana (2000), "Apocalyptic Thought and Serbian Identity: Mythology, Fundamentalism, Astrology, and Soothsaying as part of Political Propaganda", in Ethnologia Balkanica, №. 4.

33. Redjep Jelka (1991), "Die Kosovo-Legende und die Geschichte über die Kosovo-Schlacht", in Đuretić V. and Tasić N. (ed.), Kosovska bitka 1389. godine i njene posledice : međunarodni simpozijum, Beograd: SANU.

34. Ristović Milan (2001), "General M. Nedić - Diktatur, Kollaboration und die patriarchalische Gesellschaft Serbiens 1941-1944", in Erwin Oberländer (ed.), Autoritäre Regime in Ostmittel- und Südosteuropa 1919-1944, Paderborn: Ferdinand Schöningh.

35. Simpson J. R. (1986), "King Arthur's Enchanted Sleep: Early Nineteenth Century Legends", Folklore, 97(2).

36. "St. Vitus Day: Dark clouds over Kosovo again" (2007), Serbianna (28 June), at www. serbianna.com/news/2007/01909.shtml.

37. Temperley Harold W. V. (1969), History of Serbia, NY: Howard Fertig.

38. Timonen Asko (1996), 'Saint Olaf's 'cruelty': Violence by the Scandinavian King interpreted over the centuries", Journal of Medieval History, 22(3).

39. Trevelyan G. M. (1959), A Shortened History of England, Harmondsworth, Middlesex: Penguin Books, 1942; Pelican edition.

40. Williams Mary (1962), "King Arthur in History and Legend", Folklore, 73(2). 